\title{
Identifikasi Cultural Landscape Di Desa Bayung Gede, Kabupaten Bangli, Provinsi Bali
}

\author{
Anak Agung Bagus Bayu Anggawirya ${ }^{1 *}$, Syamsul Alam Paturusi ${ }^{1}$, Ciptadi Trimarianto ${ }^{1}$
}

1. Program Magister Arsitektur, Fakultas Teknik, Universitas Udayana, JL. P.B. Sudirman, Denpasar, Indonesia

*E-mail: bayuanggawirya@gmail.com

\begin{abstract}
Identification of cultural landscape in Bayung Gede Village, Bangli Regency, Bali Province. Landscape and culture are important for the sustainability of Bali tourism. The combination of landscape and culture forms a cultural landscape. For the environment, cultural landscape sustainability is very important because it contributes to biodiversity conservation. Bayung Gede Village is a Bali Aga village located in a mountainous area, with geographic conditions consisting of traditional settlements and plantation land. Bayung Gede Village has various uniqueness, but the utilization of its potential for tourism is not optimal. This research is an attempt to identify the potential cultural landscape in Bayung Gede Village. The research method used is qualitative research methods. Data collection techniques were carried out through field observations, in-depth interviews, and literature studies. The data were analyzed by using descriptive analysis techniques. From the analysis, it is concluded that most of the Bayung Gede Village area is a cultural landscape. The unique cultural landscape in Bayung Gede Village is in the form of traditional residential areas, traditional house yards, and sacred spaces. The cultural landscape of Bayung Gede Village is a cultural landscape that is deliberately designed by humans, and an associative cultural landscape, which is a combination of nature and people's beliefs.
\end{abstract}

Keywords: cultural landscape, traditional, Bali Aga, Bayung Gede Village

\section{Pendahuluan}

Kebijakan pengembangan pariwisata di Bali adalah pariwisata yang berlandaskan kebudayaan Bali dan dilaksanakan secara berkelanjutan (Perda Prop. Bali, 2012). Sejalan dengan misi kebijakan pemerintah tersebut (Hakim et al., 2009) menyatakan bahwa keberlanjutan pariwisata di Bali bergantung dari kelestarian landscape alami dan budaya. Budaya dan alam merupakan faktor penting dalam pengembangan pariwisata budaya yang berkelanjutan di Bali. Terkait dengan budaya dan landscape, Bali memiliki cultural landscape yang telah menjadi warisan budaya dunia (WBD) yaitu cultural landscape subak. Situs WBD cultural landscape subak tersebut yaitu: kawasan Catur Angga Batukaru, kawasan Pura Taman Ayun, kawasan Ulun Danu Batur dengan Danau Baturnya, dan kawasan aliran Tukad Pakerisan (Salamanca et al., 2015). Disamping cultural landscape subak masih banyak lagi potensi cultural landscape yang belum digali.

Desa Bayung Gede merupakan salah satu desa Bali Aga yang terletak di Kabupaten Bangli, yang memiliki banyak keunikan. Desa Bali Aga adalah desa yang penduduknya merupakan penduduk yang sudah bermukim di Bali sebelum kedatangan orang-orang Majapahit ke Bali (Dwijendra, 2009). Penduduk desa Bali Aga sering disebut Bali Mula. Desa Bayung Gede memiliki ciri-ciri desa Bali Aga pada umumnya yaitu pola desanya merupakan pola linier, rumah tradisionalnya sebagian besar menggunakan bahan bambu, namun juga memiliki keunikan tersendiri seperti pola rumah dan juga beberapa tradisi. Keunikan lain dari Desa Bayung Gede yaitu desa ini merupakan desa Bali Aga yang sudah mendapat pengaruh kebudayaan Hindu Bali tidak seperti Desa Trunyan dan Desa Tenganan (Jensen dan Suryani, 1996). Melalui Perbup Bangli No. 4 Tahun 2018 Desa Bayung Gede ditetapkan sebagai desa wisata. Namun, pemanfaatan potensi pariwisata di Desa Bayung Gede belum optimal, tidak seperti Desa wisata lainnya yang terdapat di Kabupaten Bangli seperti Penglipuran, ataupun desa Trunyan. Hal tersebut terlihat dari Kunjungan wisatawan ke Desa Bayung Gede belum terdata, sedangkan kunjungan wisatawan ke Desa Penglipuran tahun 2019 sebanyak 262.401 (Mercury MF, 2019), dan kunjungan wisatawan ke Desa Trunyan tahun 2017 sudah mencapai satu juta orang (Gunatama, 2017). Selain itu terdapat beberapa perubahan telah terjadi pada Desa Bayung Gede seperti perubahan typo-morphologi hunian akibat pengaruh berbagai faktor (Manik, 2007). Berdasarkan pengamatan di lapangan, salah satu potensi yang perlu digali di Desa Bayung Gede adalah cultural landscape. Cultural 
landscape sangat penting karena keberlanjutan cultural landscape dapat memberi kontribusi kepada konservasi biodiversity (Wahurwgh, 2015). Namun belum banyak penelitian terkait cultural landscape di Desa Bayung Gede. Oleh sebab itu peneliti tertarik untuk meneliti tentang cultural landscape di Desa Bayung Gede. Dalam cultural landscape terdapat simbol yang memiliki arti, karena cultural landscape adalah hasil karya manusia dengan cara mengubah lingkungan alami. Arti simbol dapat berupa gagasan, kepercayaan, dan sejarah kebudayaan yang dapat dibaca pada cultural landscape (Mills, 2007). Potensi cultural landscape pada Desa Bayung Gede dan nilai yang terkandung di dalamnya perlu diidentifikasi, untuk dapat dijadikan masukan dalam perancangan pembangunan dan pengembangannya. Penelitian ini dilakukan dengan metode kualitatif. Hasil dari penelitian ini diharapkan dapat menjadi masukan dalam mengembangkan pariwisata di Desa Bayung Gede terkait pelestarian nilai - nilai yang terkandung dalam cultural landscape.

\section{Metode Penelitian}

Penelitian ini dilakukan di kawasan Desa Bayung Gede Kecamatan Kintamani Kabupaten Bangli Provinsi Bali. Batas-batas wilayah Desa Bayung Gede yaitu: di sebelah utara Desa Batur, di sebelah timur Desa Sekardadi, di sebelah selatan Desa Bonyoh, dan di sebelah barat Desa Belancah. Lokasi Desa Bayung Gede dapat dilihat pada gambar 1.

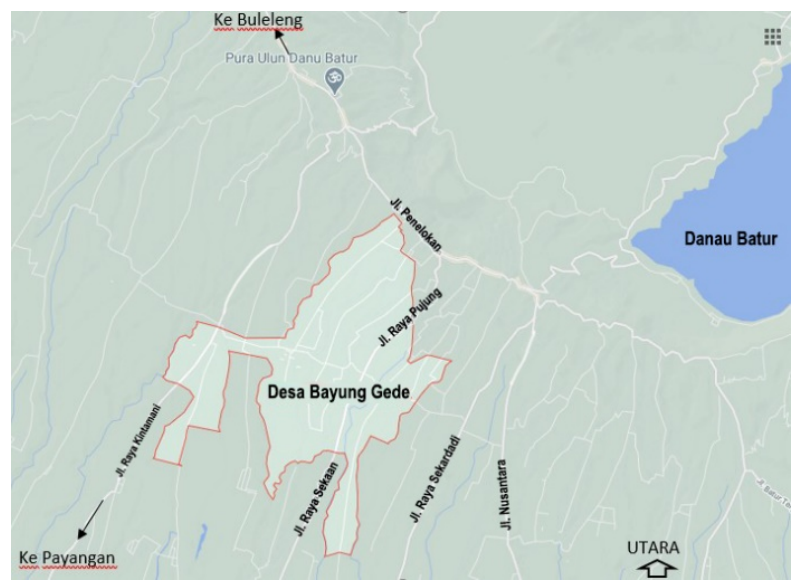

Gambar 1. Lokasi Desa Bayung Gede (diolah dari Google Maps, 2020)

Penelitian ini merupakan penelitian kualitatif. Teknik pengumpulan data dilakukan dengan metode observasi lapangan, wawancara mendalam dengan narasumber yang dianggap kompeten, dan studi literatur yaitu pengumpulan data sekunder dari sumber-sumber tertulis yang sudah ada. Narasumber yang diwawancarai dalam penelitian ini adalah tokoh masyarakat dan tokoh adat Desa Bayung Gede. Untuk pengembangan narasumber yang diwawancara dilakukan dengan snowball sampling. Teknik analisa data dilakukan dengan analisis kualitatif deskriptif. Tahap awal dilakukan perumusan indikator cultural landscape dari literatur, kesepakatan-kesepakatan, dan sumber-sumber lain. Data yang diperoleh melalui observasi lapangan, wawancara mendalam dan sumber tertulis, direduksi, dipilih dan dikelompokkan, kemudian dijabarkan makna yang terkandung di dalamnya. Pada bagian akhir disimpulkan potensi cultural landscape yang ada beserta nilai yang terkandung di dalamnya.

\section{Hasil dan Pembahasan}

\subsection{Cultural Landscape dan Kebudayaan}

Secara umum Rapoport (1992) mendefinisikan bahwa cultural landscape adalah interaksi antara aktivitas manusia dengan landscape alami. Menurut Windia (2013) cultural landscape adalah wilayah geografis yang bersifat unik dan berbeda, dari sebuah karya gabungan antara alam dan manusia. Cultural landscape juga diartikan sebagai hasil dari kebudayaan yang mencerminkan gabungan antara alam dan hasil karya manusia (UNESCO-ICOMOS, 2009). UNESCO menggolongkan cultural landscape ke dalam tiga tipe yaitu:

(1) Cultural landscape yang dirancang dan dibuat dengan sengaja oleh manusia. Cultural landscape ini paling 
mudah di identifikasi, dapat berupa taman yang dirancang untuk hal-hal yang terkait dengan estetika, dapat pula berhubungan dengan bangunan monumental, keagamaan, atau yang lain; (2) Pemandangan organik yang mengalami evolusi, sebagai akibat dari kegiatan ekonomi, sosial, administrasi, dan atau Agama, yang menunjukkan adanya proses evolusi bentuk dan fitur; (3) Cultural landscape asosiatif yang dianggap bernilai karena religi, perpaduan antara budaya atau kesenian dengan elemen alam.

Berdasarkan pengertian dan tipe cultural landscape, dapat dilihat bahwa cultural landscape sangat erat kaitannya dengan kebudayaan, oleh sebab itu maka perlu pemahaman mengenai kebudayaan. Kebudayaan adalah pikiran, karya, dan hasil karya manusia yang tidak berasal dari naluri, tetapi berasal dari pengalaman yang didapat melalui proses belajar. Unsur kebudayaan antara lain: sistem religi dan upacara keagamaan, sistem dan organisasi kemasyarakatan, sistem pengetahuan, bahasa, kesenian, sistem mata pencaharian, sistem teknologi dan peralatan (Koentjaraningrat, 1974).

Sistem religi pada masyarakat tradisional membentuk ruang sakral dan profan. Masyarakat tradisional adalah masyarakat yang religius, mereka memandang ruang sakral sebagai ruang yang nyata. Ruang sakral pada umumnya menjadi orientasi bagi ruang lainnya. Manusia dipandang menghuni wilayah dunia tengah (midland) yang berada diantara dunia luar yang tidak terkendali dan wilayah dunia dalam yang memiliki karakter sakral. Kedua ruang ini, wilayah tengah dan dalam dipandang memiliki kualitas kesucian. Kualitas kesucian ini selalu diperbaharui melalui berbagai kegiatan ritual sakral. Kegiatan ritual dilakukan dalam suatu tempat pada ruang sakral ini. Kegiatan ritual ini menjadi cara untuk membersihkan kembali ruang profan menjadi ruang sakral. Ruang yang berkarakter sakral lebih kokoh dan bermakna. Ruang lainnya yang profan dipandang tanpa makna. Manusia tradisional pada umumnya tidak mampu untuk hidup nyaman dalam suasana dunia yang profan, karena mereka tidak mampu mengorientasikan dirinya (Eliade, 1987). Ruang sakral pada masyarakat Bali pada umumnya berupa landscape dengan batas teritori yang jelas. Tempat suci umat Hindu di Bali khususnya pura, merupakan suatu areal yang dibatasi oleh tembok penyengker (dinding) yang di dalamnya terdapat beberapa bangunan yang memiliki fungsi tertentu. Susunan ruang pekarangan dengan tata nilai kepala, badan, kaki, atau utama, madya, nista. Jeroan sebagai kepala, jaba tengah sebagai badan, dan jaba sisi sebagai kaki. Jaba sisi berfungsi sebagai ruang peralihan dari suasana publik di luar pura. Jaba tengah merupakan areal yang biasanya digunakan untuk persiapan upacara, jeroan adalah areal utama pura yang terdapat bangunan-bangunan pemujaan (Gelebet, 1986). Pura merupakan areal yang di dalamnya terdapat landscape (ruang luar), bangunan pemujaan, dan bangunan penunjang. Dengan demikian pura merupakan cultural landscape.

\subsection{Gambaran Umum Desa Bayung Gede}

Desa Bayung Gede berada di daerah pegunungan dengan ketinggian $900 \mathrm{~m}$ diatas permukaan laut. Kontur tanah desa ini memiliki kemiringan lebih kurang $10^{\circ}$ kearah selatan. Struktur tanah Desa Bayung Gede adalah tanah regosol berhumus dengan suhu rata-rata berkisar $20^{\circ}$ (bayunggede.desa.id). Sebagian besar penduduk Desa Bayung Gede adalah petani. Tanaman yang dapat tumbuh di areal desa ini adalah: jagung (zea mays), ketela (manihot esculenta), pisang (musa), jeruk (citrus), jambu (psidium guajava) dan sayursayuran. Tanaman yang paling dominan adalah jeruk (citrus). Tanaman yang ada di Desa Bayung Gede dibagi menjadi dua kelompok yaitu tanaman yang dibudidayakan, dan tanaman yang tumbuh liar. Tanaman yang dibudidayakan tumbuh pada lahan perkebunan yaitu: jagung (zea mays), kacang tanah (arachis hypogaea), kacang kedelai (glycine max), kacang hijau (vigna radiata), dan jeruk (citrus). Tanaman yang tumbuh liar adalah bambu dan tanaman hutan. Tanaman bambu merupakan tanaman yang dominan mengelilingi permukiman. Ternak yang dominan dipelihara oleh penduduk adalah sapi dan babi. Pemeliharaan hewan ternak dilakukan diluar permukiman (di tegalan) karena ada peraturan adat yang mengatur tentang pemeliharaan ternak yang tidak boleh dilakukan pada pekarangan rumah. Luas Desa Bayung Gede sekitar 1.024 Ha yang terdiri dari Perumahan, fasilitas umum, jalan, pekuburan, tegalan, dan lain-lain. Peruntukan lahan yang dominan adalah tegalan (monografi desa, 2006).

Sarana pelayanan lingkungan yang ada di Desa Bayung Gede meliputi tempat suci/pura, balai pertemuan, kantor kepala desa, sekolah (SD, SMU), Lembaga Perkreditan Desa, Puskesmas, warung, dan setra (kuburan). Tempat suci/pura terdiri dari pura umum dan Pura Dadia (pura keluarga). Pura umum yaitu: Pura Puseh, Pura Bale Agung, Pura Dalem, Pura Puseh Pingit, Pura Pelampuan, Pura Ibu, Pura Penyimpenan. 
Pura dadia antara lain: Pura Tangkas, Pura Panti Kayu Selem, Pura Pasek Gelgel. Setra (kuburan) terdiri dari lima setra yaitu: Setra Gede, Setra Penyampingan, Setra Pengerancab, Setra Anak, Setra Ari-ari. Prasarana pelayanan lingkungan yang ada meliputi: Rurung gede (Jalan utama), gang, parkir, saluran drainase. Jalan utama berada ditengah permukiman menjadi poros desa, yang pada hulunya (bagian utara) terdapat Pura Bale Agung dan pada bagian hilir (selatan) terdapat setra. Gang merupakan sirkulasi sekunder sebagai akses dari pekarangan menuju ke jalan utama.

Penduduk Desa Bayung Gede saat ini berjumlah 2.448 jiwa yang terdiri dari 1.245 jiwa laki-laki, dan 1.203 jiwa perempuan (bayunggede.desa.id). Penduduk ini bermukim pada permukiman tradisional dan diluar permukiman tradisional. Permukiman tradisional memiliki pekarangan dengan status pekarangan tanah desa. Masyarakat yang tinggal pada permukiman tradisional yang sudah menikah hanya diperbolehkan tinggal selama satu tahun pada permukiman tradisional tersebut, dan selanjutnya keluar dari permukiman tradisional dan tinggal diluar permukiman tradisional. Pekarangan tanah desa akan ditempati oleh anak laki-laki paling bungsu dan menyandang status krama ngarep (warga desa inti yang mempunyai hak dan kewajiban penuh sebagai warga adat) (Manik, 2007). Daerah permukiman penduduk terpusat di tengah desa dan dikelilingi oleh perkebunan. Permukiman pada Desa Bayung Gede terdiri dari kawasan permukiman tradisional dan kawasan pengembangan. Kawasan permukiman tradisional merupakan permukiman awal sebelum mengalami perkembangan. Kawasan permukiman pengembangan adalah kawasan permukiman yang dikembangan untuk masyarakat yang tidak bisa lagi tinggal di permukiman tradisional. Kawasan permukiman dan fasilitasnya dapat dilihat pada gambar 2.

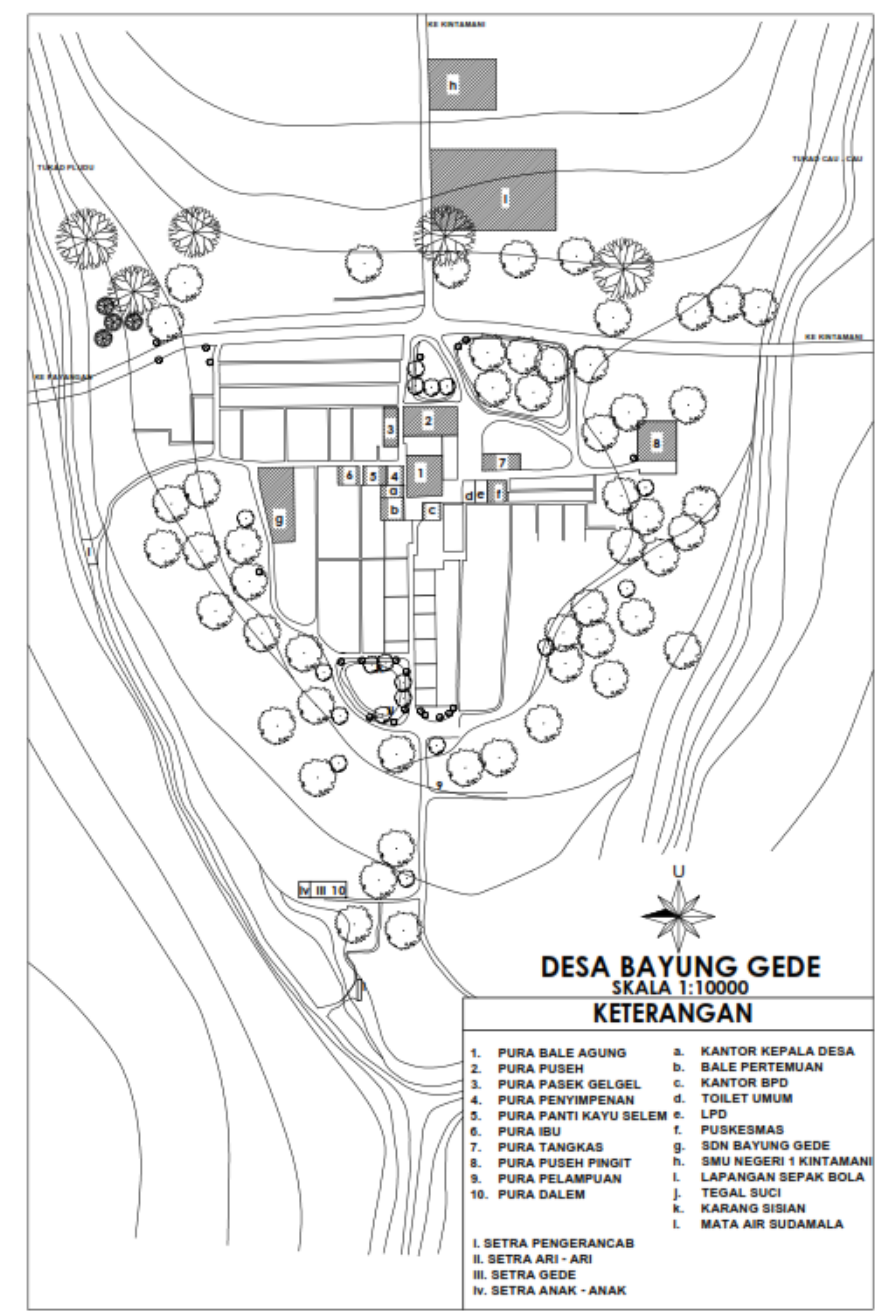

Gambar 2. Peta kawasan permukiman dan fasilitasnya di Desa Bayung Gede (Manik, 2007 dan observasi 2020) 


\subsection{Cultural Landscape Desa Bayung Gede}

\subsubsection{Pola Desa dan Perumahan Tradisional}

Secara tipologi, Desa Bayung Gede adalah desa Bali Aga yang merupakan peninggalan jaman Bali

Kuno. Pusat permukiman dan pemerintahan adatnya berada pada daerah pedalaman atau pegunungan. Mata pencaharian masyarakatnya sebagian besar sebagai petani dan peternak. Desa Bayung Gede dikelilingi oleh tegalan dan diapit dua buah sungai yaitu Tukad Pludu dan Tukad Cau-cau (Dwijendra dan Manik, 2007).

Dalam penataan desa tercermin bahwa arah kaja (utara) merupakan arah yang yang lebih utama (sakral) dan arah kelod (selatan) merupakan arah yang lebih nista (profan). Kaja dianggap lebih utama karena terdapat Gunung Tohlangkir (Gunung Agung), Gunung Lebah (Gunung Batur) dan Gunung Nerajong (Bukit Penulisan) yang menurut pandangan masyarakat setempat merupakan payogan ida betara (tempat beristananya Tuhan). Hal ini tercermin pada pola desa dimana Pura Bale Agung, Pura Puseh, Pura Puseh Pingit dan Tegal Suci berada di bagian kaja (utara) atau hulu, dan kuburan berada di bagian kelod (selatan).

Tata guna lahan yang ada di lingkungan perumahan, dapat dikelompokkan kedalam tiga zona pokok yaitu: zona utama / hulu, yang terletak pada bagian utara desa dengan posisi yang paling tinggi dan terdapat pura, antara lain: Pura Puseh, Pura Bale Agung, Pura Puseh Pingit, Pura Penyimpenan, Pura Pasek Gelgel, Pura Panti Kayu Selem, Pura Ibu, Pura Tangkas, dan Tegal Suci. Pada zona madya di bagian tengah terdapat pekarangan rumah, bale banjar, bale kulkul, karang sisian (zona perumahan yang diperuntukkan bagi orang yang melakukan pelanggaran adat, antara lain menikahi kerabat seperti sepupu). Pada zona nista / teben, di selatan desa terdapat Setra Ari-ari, yaitu kuburan khusus untuk meletakkan ari-ari atau plasenta bayi yang dibungkus dengan batok kelapa dan digantung pada pohon. Pada bagian selatan atau bagian yang paling rendah terdapat Setra Anak, Setra Gede, Pura Pelampuan, dan Pura Dalem. Yang unik adalah terdapat Setra Pengerancab yang digunakan untuk orang yang meninggal secara tidak wajar, tetapi kini sudah tidak digunakan, jadi secara fungsional sudah tidak berfungsi lagi. Setra Pengerancab ini terdapat pada daerah yang rendah tetapi tidak di bagian selatan desa melainkan pada bagian barat desa. Dengan pembagian zona tersebut pola tata guna lahan menunjukkan penggunaan konsep hulu-teben dengan pembagian zona dibagi menjadi tiga yaitu utama, madya, nista. Pola tata guna lahan yang ada dilatar belakangi oleh sistem kepercayaan yaitu bahwa arah gunung dan daerah yang lebih tinggi bernilai lebih suci/sakral sedangkan arah laut dan daerah yang lebih rendah bernilai lebih profan.

Pola jaringan jalan yang membentuk lingkungan perumahan tradisional Desa Bayung Gede terdiri dari rurung gede (jalan utama) yang membentang dari arah utara (Pura Bale Agung) kearah selatan menuju setra (Setra Ari-ari, Setra Gede dan Setra Anak). Disamping sebagai jalan utama, jalan ini yang juga berfungsi sebagi core (pusat). Ada juga jalan-jalan kecil / gang-gang kearah utara selatan dan juga timur barat. Selain jalan utama tersebut terdapat juga jalan besar lainnya yaitu dari Pura Bale Agung ke timur menuju ke pura Puseh Pingit dan ke barat menuju ke Setra Pengerancab. Jalur sirkulasi ini digunakan dengan pola tertentu untuk upacara adat sesuai dengan jenis upacaranya. Misalnya pada pada upacara mianin yaitu upacara sejenis ngaben dilakukan dengan pola sirkulasi tertentu. Di Desa Bayung Gede tidak dilakukan pembakaran mayat tetapi dilakukan penguburan, kemudian dilakukan upacara mianin yang prosesinya dilakukan dengan pembakaran cangku (simbol jasad orang yang sudah meninggal). Jalur sirkulasinya adalah sebagai berikut: cangku dan sarana upacara lain yang disebut bakti dari rumah orang yang meninggal dibawa ke Pura Bale Agung, kemudian dibawa ke Tegal Suci untuk diupacarai, dan diprelina (dibakar). Sarana upacara lain yang disebut sagi dibawa ke kuburan oleh para pemuda melalui rurung gede / jalan utama, dan dilakukan prosesi upacara lagi di setra / kuburan. Medeheng juga merupakan ritual yang dilakukan dengan jalur sirkulasi tertentu. Medeheng adalah ritual yang dilakukan oleh pemuda-pemudi dengan jalur sirkulasi dari pura Bale Agung melewati rurung gede menuju ke Pura Pelapuan. Jalur sirkulasi selain digunakan untuk sirkulasi kegiatan sehari-hari juga digunakan untuk kegiatan upacara adat. Pola sirkulasi erat kaitannya dengan ritual yang terkait dengan kepercayaan.

Pekarangan tradisional pada Desa Bayung Gede adalah pekarangan tanah desa. Pekarangan tanah desa adalah pekarangan milik desa adat yang ditempati oleh satu kepala keluarga (krama ngarep) yang memilik hak dan kewajiban penuh terhadap ketetapan desa adat yang berlaku. Keluarga yang tidak termasuk krama ngarep akan membuat rumah di luar desa tradisional hal ini menyebabkan jumlah pekarangan rumah tradisional tetap terjaga dengan kata lain sistem sosial membentuk pola permukiman desa adat. 
Pekarangan pada permukiman tradisional Desa Bayung Gede berbentuk persegi empat yang memanjang kearah timur-barat. Kontur tanah pada areal desa menurun tajam kearah utara selatan. Pekarangan memanjang searah dengan garis kontur, hal ini mengakibatkan cut and fill lebih sedikit dilakukan daripada pekarangan dibuat memanjang ke arah utara-selatan atau tegak lurus dengan garis kontur. Sistem pengetahuan yang dimiliki membentuk pola permukiman.

\subsubsection{Pekarangan dan Rumah Tradisional}

Unit pekarangan dan rumah tradisional Desa Bayung Gede memiliki karakteristik yang unik. Unit pekarangan berbentuk memanjang yang dihubungkan oleh jalan kecil (gang) menuju ke rurung gede / jalan utama (core). Pekarangan di tata dengan konsep hulu-teben yang terdiri dari: sanggah di bagian hulu (utama), paon dan bale pegaman di bagian tengah (madya), dan lumbung di bagian teben (nista). Di bagian tengah pekarangan terdapat paletasan (bukaan pada tembok pekarangan) untuk memudahkan sirkulasi dan komunikasi penghuni rumah yang satu dan lainnya. Fasilitas yang ada dalam unit pekarangan yaitu: (1) Sanggah berfungsi sebagai tempat pemujaan kepada Tuhan dan kepada para roh leluhur yang telah suci. Sanggah berada di bagian paling belakang pekarangan rumah tinggal (berada di zona hulu). Penataan pekarangan rumah didasari oleh sistem religi atau kepercayaan. Zona yang paling sakral / utama dalam pekarangan adalah bagian paling dalam sedangkan zona yang paling profan / nista adalah zona paling luar.

Bentuk bangunan pelinggih (bangunan pemujaan) sangat sederhana dengan bentuk turus lumbung (tiang dari pohon dadap yang dibiarkan hidup, serta tempat menaruh persembahan dan penutup menggunakan anyaman bambu). Pelinggih yang minimal ada adalah pelinggih Bhatara Guru dan pelinggih Taksu. Uniknya pelinggih Bhatara Guru ini akan dilepas atau dicabut jika pemilik rumah ini sudah meninggal (ayah \& ibu), tepatnya pada saat upacara mianin (ngaben). Bagi pengantin baru yang menempati pekarangan rumah tersebut harus membangun palinggih Bhatara Guru yang baru di sanggah. Pembedaan nilai antara natah (halaman) tempat suci dengan natah umah / halaman rumah dilakukan dengan membedakan ketinggian / level, dimana level natah sanggah dibuat lebih tinggi dari natah umah; (2) Dapur mempunyai fungsi cukup banyak, mulai dari tempat memasak, tempat tidur orang tua, dan fungsi sakral. Proses kelahiran dan upacara kematian berlangsung pada bangunan ini. Orang yang menikah atau melahirkan akan tinggal di dapur sampai 42 hari. Dapur juga berfungsi untuk tempat membaringkan jasad orang yang sudah meninggal sebelum dibawa ke kuburan. Sesuai dengan iklim setempat yang relatif dingin, dapur tidak banyak memiliki bukaan. Sirkulasi udara berlangsung melalui pintu serta celah pada bagian atas ruangan tepatnya pada celah antara dinding dan atap. Pada ruangan dapur terdapat peralatan sesuai dengan aktivitas di dapur yaitu: tungku untuk memasak, langgatan untuk tempat menaruh sesaji, tempat menyimpan peralatan memasak berbentuk seperti rak, bale untuk tempat tidur, dan pelangkiran untuk tempat menghaturkan sesajen. Aktivitas yang dilakukan di dapur mencerminkan bahwa dapur dimanfaatkan secara optimal. Orang tua, pengantin, bayi, tidur di dapur yang relatif lebih hangat dari ruangan lainnya; (3) Bale Pengaman menggunakan bentuk bale saka nem (bangunan bertiang enam) dan ditutup dengan gedeg di seluruh sisi bangunannya. Dari interiornya terlihat bale pegaman dibagi menjadi dua bagian, bagian yang tertutup disebut bale kapingitan, saat ini berfungsi sebagai tempat menaruh sokasi / perlengkapan persembahyangan. Bagian bale yang terbuka berfungsi sebagai tempat metanding banten (merangkai banten), serta tempat upacara ngerorasin (upacara dua belas hari). Saat ini bale yang terbuka juga berfungsi sebagai tempat tidur untuk anak; (4) Pada zona teben di pekarangan rumah tinggal terdapat lumbung dengan bentuk sakepat (bertiang empat). Bagian bawah lumbung berfungsi sebagai tempat meletakkan hasil \& alat-alat pertanian dan perkebunan. Sementara pada bagian atasnya merupakan tempat untuk menyimpan padi. Bagian yang unik pada lumbung adalah tidak adanya langki (kayu berbentuk segi empat diatas tiang bangunan yang berfungsi untuk mencegah tikus naik ke lumbung) seperti lumbung pada umumnya, namun fungsinya digantikan oleh lambang mayeng (balok kayu) yang tebal dan lebar.

Fasilitas yang ada pada rumah tradisional Desa Bayung Gede sesuai dengan mata pencaharian penghuninya, seperti tersedianya lumbung untuk menyimpan hasil bumi dan peralatan berkebun. Wujud bangunan sesuai dengan pengetahuan yang dimiliki seperti minimnya bukaan menunjukkan upaya mengatasi udara dingin. Bahan bangunan yang digunakan merupakan bahan bangunan setempat seperti bambu, dan jenis kayu yang tumbuh pada lingkungan setempat. Pekarangan tradisional Bayung Gede dapat dilihat pada gambar 3 dan gambar 4 . 


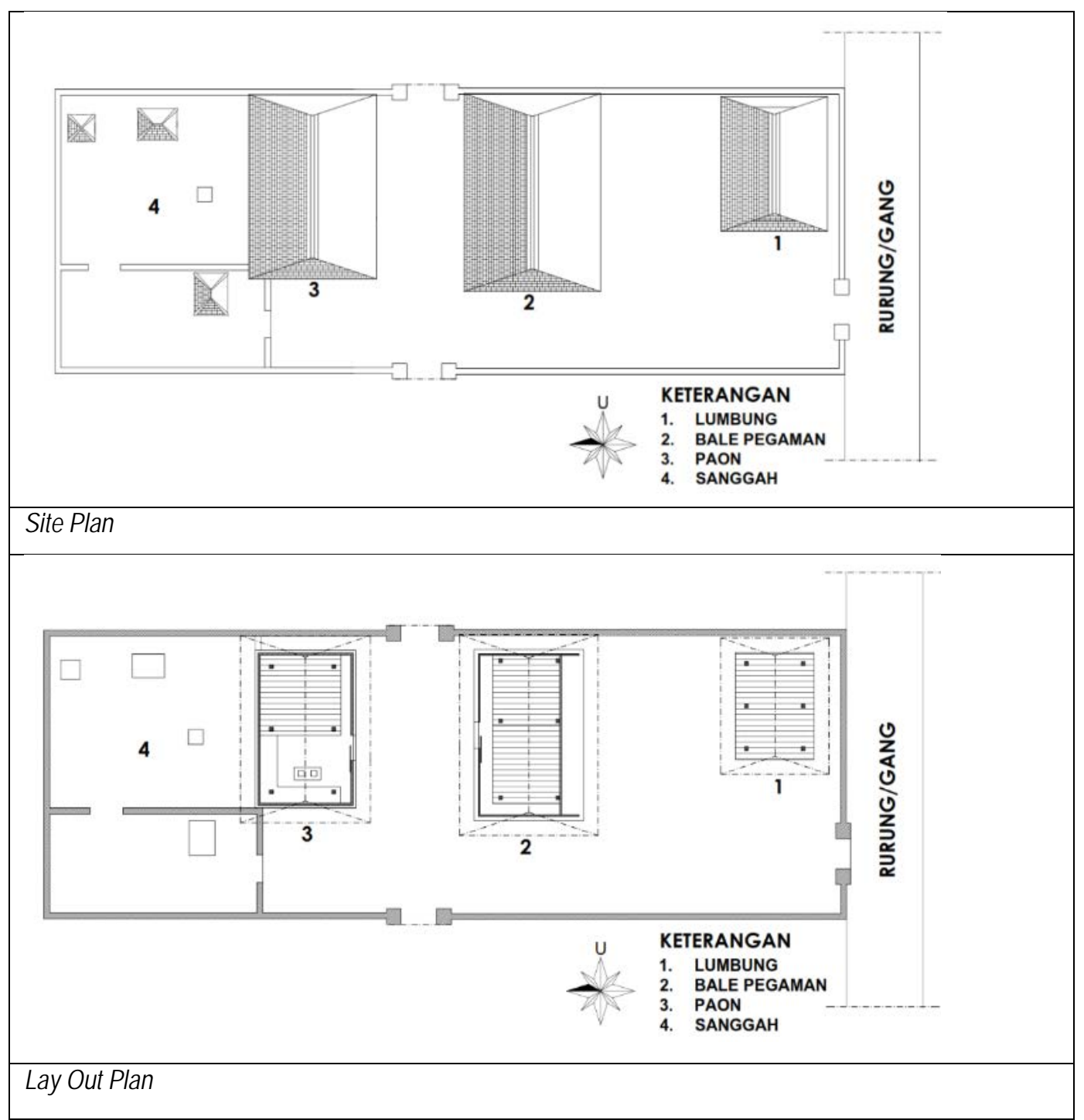

Gambar 3. Pekarangan rumah dengan bangunan tradisional di Desa Bayung Gede (Idedhyana, 2011)

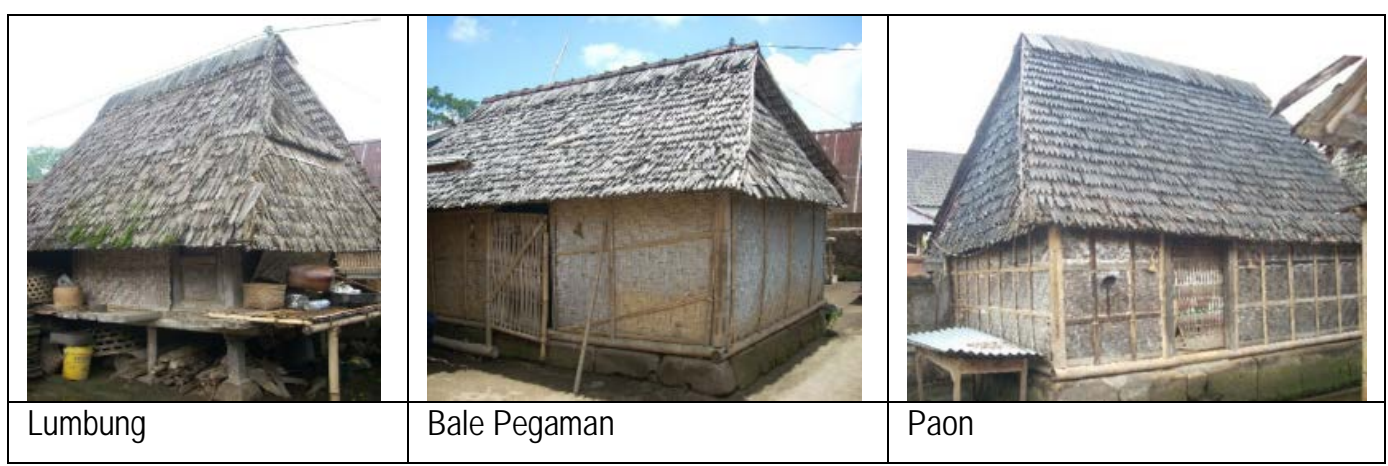

Gambar 4. Bangunan tradisional pada pekarangan rumah di Desa Bayung Gede

Bangunan pada pekarangan tradisional di Desa Bayung Gede memiliki beberapa kesamaan dengan arsitektur tradisional Bali dataran (yang bersumber pada asta kosala kosali) namun memiliki kekhasan tersendiri. Beberapa kesamaan antara lain ukuran dan jarak saka (tiang) pada bale pegaman, paon, dan lumbung, sesuai dengan Arsitektur Tradisional Bali (ATB) dataran. Hal yang berbeda dengan ATB adalah penggunaan material bangunan yaitu adanya penggunaan kayu dis, kayu dadap, kayu jempinis (Idedhyana, 
2011). Keunikan lain adalah pengorganisasian ruang pada masa bangunan, dan adanya tipologi bale pegaman yang tidak ditemukan di daerah lain. Dengan demikian pekarangan rumah terdiri dari landscape dan bangunan tradisional yang memiliki fungsi sakral dan profan.

\subsubsection{Tempat Suci}

Tempat suci yang ada di Desa Bayung Gede terdiri dari tempat suci yang bersifat umum dan pura dadya yaitu pura keluarga. Tempat suci umum antara lain: Pura Puseh, Pura Bale Agung, Pura Dalem, Pura Puseh Pingit, Pura Penyimpenan, dan Pura Pelampuan. Pura dadya antara lain: Pura Ibu, Pura Tangkas, Pura Panti Kayu Selem, Pura Pasek Gelgel. Pura Bale Agung, Pura Puseh dan Pura Dalem adalah pura umum yang bersifat teritorial yaitu disungsung (dimiliki, dirawat dan difungsikan oleh masyarakat di suatu wilayah). Secara fungsi pura di Desa Bayung Gede serupa dengan daerah lain di Bali namun secara fisik memiliki keunikan. Keunikan Pura Bale Agung antara lain pada pencapaian yaitu apabila memasuki areal utama mandala pura (jeroan) harus melalui jalan yang disebut titi gonggang, setelah itu baru bisa masuk ke jeroan pura. Titi gonggang adalah jembatan sempit yang dibawahnya terdapat galian (lubang). Pura dadya adalah pura untuk pemujaan suatu keluarga besar (klan) serupa dengan pura dadya di daerah lain di Bali namun juga memiliki keunikan secara fisik. Pura puseh pingit merupakan pura yang unik, yaitu ritualnya hanya dilakukan oleh pemuda-pemudi dan bapak-bapak, sedangkan untuk ibu-ibu, hanya yang telah mengikuti upacara khusus yang boleh melakukan upacara dan pemujaan. Keunikan fisik bangunan pura adalah pada atap bangunan yang menggunakan sirap bambu. Kondisi fisik beberapa pura dapat dilihat pada gambar 5 .

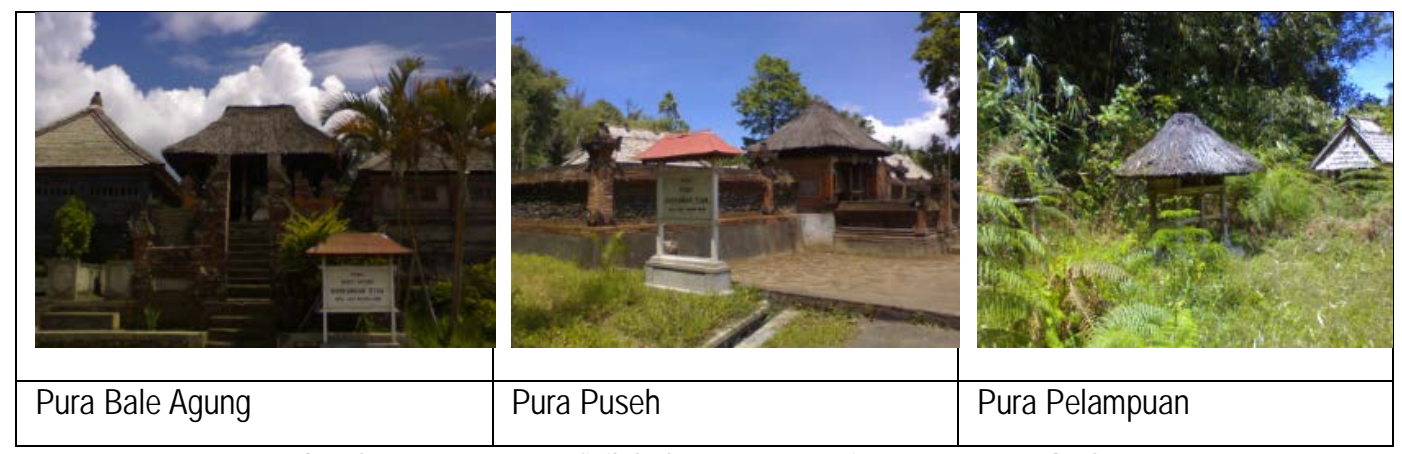

Gambar 5. Bangunan fisik beberapa Pura Di Desa Bayung Gede

Zona (tata letak) tempat suci didasari atas kepercayaan terhadap arah gunung merupakan arah yang lebih suci. Keunikan tempat suci di Desa Bayung Gede adalah pada wujud bangunannya yaitu penggunaan atap sirap bambu, sesuai dengan potensi alam setempat dan teknologi dalam membangun yang dimiliki. Hal ini memberikan tampilan yang khas pada fitur landscape tempat suci.

\subsubsection{Setra (kuburan)}

Di Desa Bayung Gede terdapat lima setra (kuburan) yang dibedakan sesuai fungsinya antara lain: Setra Gede, Setra Penyampingan, Setra Pengerancab, Setra Anak, dan Setra Ari-ari. Setra Gede adalah kuburan untuk orang yang meninggal secara wajar, tidak memiliki cacat fisik atau mental, dan tidak meninggal bersamaan dengan upacara di pura yang ada di Desa Bayung Gede dan pura-pura terkait. Setra Penyampingan adalah kuburan untuk orang yang meninggal pada saat ada upacara adat di Desa Bayung Gede dan pura-pura terkait. Setra Pengerancab adalah kuburan untuk orang yang meninggal secara tidak wajar (salah pati), yang prosesi penguburannya dilakukan dengan tidak disertai upacara. Setra Anak diperuntukkan bagi anak-anak yang meninggal, yaitu anak-anak yang belum meketus (belum pernah tanggal gigi). Setra Ari-ari adalah kuburan yang diperuntukkan untuk penguburan ari-ari (plasenta). Masing-masing proses penguburan dilaksanakan dengan prosesi yang khusus. Secara fisik landscape pekuburan tidak jauh berbeda dengan daerah lainnya di Bali. Hal yang unik adalah adanya Setra Ari-ari dan Setra Pengerancab. Keberadaan Setra Ari-ari merupakan wujud dari budaya setempat yang memperlakukan ari-ari secara khusus. Ari-ari tidak dikubur tetapi ditaruh pada batok kelapa dan digantung pada pohon. Keberadaan Setra Pengerancab yang kini tidak digunakan lagi menunjukkan ilustrasi fase perkembangan sosial, dimana nilainilai sosial dapat berubah sesuai dengan perkembangan jaman. Setra ari-ari dapat dilihat pada gambar 6 . 


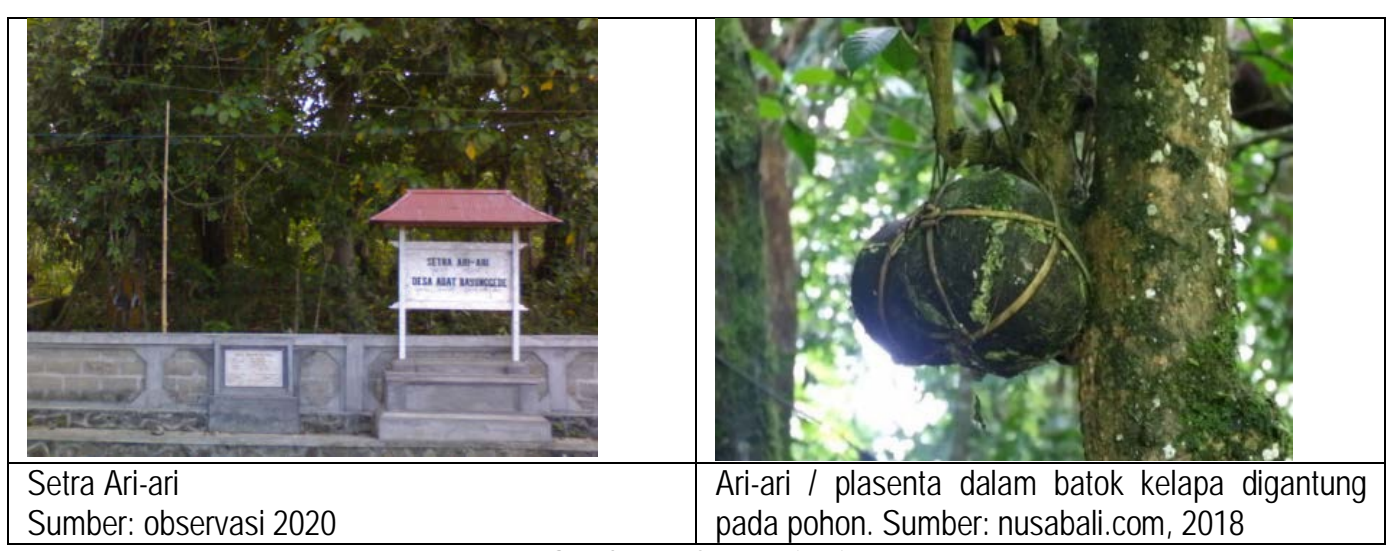

Gambar 6. Setra Ari-Ari

\subsection{Nilai-nilai pada Cultural Landscape Desa Bayung Gede}

Secara keseluruhan cultural landscape yang terdapat di Desa Bayung Gede meliputi kawasan permukiman tradisional, pekarangan rumah tradisional, cultural landscape fasilitas religi baik terkait dengan Tuhan maupun leluhur. Cultural landscape Tersebut termasuk dalam: (1) Cultural landscape yang dirancang dan dibuat secara sengaja oleh manusia dan (2) Cultural landscape asosiatif. Nilai-nilai yang terkandung pada cultural landscape Desa Bayung Gede dapat dilihat pada tabel 1.

Tabel 1. Cultural Landscape Desa Bayung Gede dan Nilai yang Terkandung

\begin{tabular}{llrl}
\hline No & Objek & Nilai (value) \\
\hline 1 & $\begin{array}{l}\text { Kawasan } \\
\text { tradisional }\end{array}$ & permukiman & $\begin{array}{l}\text { Pola desa tradisional unik, yang terlahir dari aktivitas budaya yang } \\
\text { terkait dengan religi, sistem tata ruang, dan sistem sosial. }\end{array}$ \\
2 & $\begin{array}{l}\text { Pekarangan } \\
\text { tradisional }\end{array}$ & rumah & $\begin{array}{l}\text { Pola pekarangan rumah unik yang terlahir dari aktivitas budaya yang } \\
\text { terkait dengan religi, mata pencaharian, dan sistem konstruksi. } \\
\text { Pola areal sakral yang terlahir dari aktivitas budaya yang terkait dengan } \\
\text { religi }\end{array}$ \\
4 & Areal sakral & Pola areal yang terkait dengan religi, dan perkembangan sosial \\
\hline
\end{tabular}

\section{Simpulan}

Secara umum sebagian besar wilayah Desa Tradisional Bayung Gede merupakan cultural landscape. Cultural landscape Desa Tradisional Bayung Gede terdiri dari: (1) Cultural landscape yang dirancang dan dibuat secara sengaja oleh manusia yang berupa tempat suci atau Pura, kawasan permukiman tradisional, dan pekarangan rumah tradisional. Perwujudan cultural landscape tempat suci didasari oleh kepercayaan dan potensi alam setempat yang dimiliki. Cultural landscape kawasan permukiman terpola oleh kepercayaan, sistem sosial dan sistem tata ruang. Pola ruang dan wujud fitur cultural landscape pekarangan rumah didasari oleh kepercayaan, mata pencaharian, dan sistem konstruksi bangunan (2) Cultural landscape asosiatif yaitu gabungan karya manusia dan alam berupa pekuburan yang unik. Perwujudan Cultural landscape pekuburan didasari oleh kepercayaan masyarakat setempat.

\section{$6 \quad$ Daftar Pusataka}

Camat Kintamani. 2006. Monografi Desa Bayung Gede. (tidak diterbitkan). Bangli.

Dwijendra, N. K. A. 2009. Arsitektur \& Kebudayaan Bali Kuno. Denpasar: Udayana University Press.

Dwijendra, N.K.A., Manik, I.W.Y. 2007. Transformasi Tipo Morfolofi Hunian di Desa Bayung Gede, Bali. Bali: Malakah Seminar Departemen P.U Provinsi Bali.

Eliade, Mircea. TT. 1987. The Sacred and The Profane the Nature of Religion. New York: Trask W.R. (tr). A Harvest Book. 
Gelebet, IN., Meganada, IW., Negara, IM.Y., Suwirya, IM. 1986. Arsitektur Tradisional Daerah Bali. Denpasar: Departeman Pendidikan dan Kebudayaan.

Gunatama, G., Divayana, D.G.H., Parma, IP.G., Sukerti, N.W. 2017. IbDM Geowisata Bali Aga di Desa Trunyan Kecamatan Kintamani-Bali. Prosiding Seminar Nasional Pengabdian Kepada Masyarakat.

Hakim, L., Jae, E.K., Sun, K.H. 2009. Cultural Landscape and Ecotourism in Bali Island, Indonesia. J.Ecol. Field.Biol. 32(1):1-8.

Idedhyana, IB. 2011. Perpaduan Budaya Pada Rumah Tradisional di Desa Bayung Gede. Jurnal Widya Teknik 4(1):49-65.

Jensen, GD, Suryani, LK. 1996. Orang Bali. Bandung: Penerbit ITB.

Kintamani, Camat. Monografi Desa Bayung Gede. 2006. (tidak diterbitkan). Bangli.

Koentjaraningrat. 1974. Kebudayaan, Mentalitet dan Pembangunan. Jakarta: Gramedia.

Manik, IWY. 2007. Pengaruh Demografi, Gaya Hidup, dan Aktivitas, Terhadap Transformasi Tipo-Morfologi Hunian Tradisional di Desa Bayung Gede Bangli. Tesis (tidak diterbitkan) Institut Teknologi Bandung.

MF, Mercury. 2019. Tingkat Kunjungan Wisatawan Ke Desa Penglipuran Meningkat. Diakses pada 11 Desember 2020: tersedia pada https://bali.tribunnews.com/2019/12/30.

Mills, J.G. 2007. The Category of the Associative Cultural Landscape as A Mean to Preserve Intangilble Heritage, Especially Oral Literature. Hawai'i volcanoes National Park, as an Example. Master Thesis. (unpublished) Brandenburg University of Technology.

Pastika, MM. 2012. Peraturan Daerah Propisi Bali Nomor 2 Tahun 2012 Tentang Kepariwisataan Budaya Bali. Denpasar: Pemeritah Daerah Provinsi Bali.

Rapoport, A. 1992. On Cultural Landscape. Traditional Dwellings and Settlements 3(2):33-47.

Salamanca, A.M., A. Nugroho, M. Osbeck, S. Bharwani and N. Dwisasanti. 2015. Managing a Living Cultural Landscape: Bali's Subaks and The UNESCO World Herritage Site. Stockholm Environment InstituteAsia, Bangkok.

UNESCO-ICOMOS. 2009. World Heritage Cultural Landscape. Paris: UNESCO-ICOMOS.

Wahurwgh, A., Dongre, A. 2015. Burhanpur Cultural Landscape Conservation: Inspiring Quality for Sustainable Regeneration. Sustainability 7:932-946

Windia, W, Wiguna, W.A.A. 2013. Subak Warisan Budaya Dunia. Denpasar: Udayana University Press. 